\title{
Adsorption of Silver (I) From Aqueous Solution Using Chitosan/Montmorillonite Composite Beads
}

\author{
Thanut Jintakosol ${ }^{a}$, Walaikorn Nitayaphat ${ }^{b}$ \\ ${ }^{a}$ Department of General Science, Faculty of Science, Srinakharinwirot University, Bangkok, Thailand \\ ${ }^{b}$ Department of Home Economics, Faculty of Science, Srinakharinwirot University, Bangkok, Thailand
}

Received: December 4, 2015; Revised: June 17, 2016; Accepted: July 29, 2016

\begin{abstract}
Chitosan/montmorillonite (CTS-MMT) composite beads were used as adsorbents for the removal of silver ion $\left(\mathrm{Ag}^{+}\right)$from aqueous solution. Equilibrium adsorption was achieved within $150 \mathrm{~min}$ at $3 \%$ MMT of chitosan solution. The optimum $\mathrm{pH}$ value for $\mathrm{Ag}^{+}$removal was found to be 6-7. The maximum adsorbent dosage for $\mathrm{Ag}^{+}$removal was $5 \mathrm{~g} / \mathrm{L}$. Under above maximum conditions the $\mathrm{Ag}^{+}$removal was $95.7 \%$. The maximum adsorption capacities of CTS and CTS-MMT composite beads as obtained from Langmuir isotherm were found to be 38.46 and $43.48 \mathrm{mg} / \mathrm{g}$, respectively. The adsorption kinetic agrees well with the pseudo second order model. The $\mathrm{Ag}^{+}$desorption of CTS-MMT composite bead was $17.39 \%$ at $\mathrm{pH}=4$. SEM/EDX images confirm that after adsorption the $\mathrm{Ag}^{+}$were dispersed onto the composite bead surface. The adsorption and desorption experiment demonstrated that the CTS-MMT composite beads can be used as an effective adsorbents for removal of $\mathrm{Ag}^{+}$from aqueous solution.
\end{abstract}

Keywords: Adsorption, Chitosan, Composite, Montmorillonite, Silver

\section{Introduction}

The pollution of water resources due to the indiscriminate disposal of heavy metal ions has been causing worldwide concern. Wastewater from many industries, such as metallurgical, mining, tannery, chemical manufacturing, and battery manufacturing industries, contains one or more toxic metal ions ${ }^{1}$. Therefore, the remediation of heavy metal ions from the industrial wastewaters is great interested.

Silver is the one of the precious metals that has significant roles in many parts of human life ${ }^{2}$. Due to its excellent properties, for instance, malleability, ductility, electrical and thermal conductivity, corrosion and oxidation resistance, antimicrobial and luster, Silver has been extensively investigated for various uses in industrial activities including the production of mirrors, photographic films, electroplating, catalyst, antimicrobial material, batteries and electronic devices, and jewelry ${ }^{3,4}$. Therefore, all these industrial activities have been given the silver ion pollution in wastewaters. The contact with soluble silver compounds may create some toxic effects, for example, argyria, a disease related to skin pigmentation, liver and kidney degeneration and respiratory disorders ${ }^{5,6}$.

The toxicity and high economic value of silver result in the requirement of a treatment that both remove the silver from wastewater and recover a valuable material. A variety techniques have been developed to remove the silver from wastewater such as ion-exchange ${ }^{4,7}$, precipitation $^{8}$, solid phase extraction $^{9}$, coagulation ${ }^{10}$, biosorption ${ }^{11}$ and adsorption ${ }^{12}$. Adsorption is an attracted attention because of new material types available for the recovery process. Several research studies have been focused on the utilization of the natural

\footnotetext{
* e-mail: thanut@g.swu.ac.th
}

adsorbents which are extracted from agriculture wastes and seafood by-products ${ }^{13-17}$ due to their biodegradability and eco-friendly properties.

Among these natural materials, chitosan has been proved to be a suitable biopolymer for the removal of metal ions from aqueous solution ${ }^{18-21}$. Chitosan is chemically identical to cellulose except that the hydroxyl groups in the cellulose molecule are substituted with amino groups in chitosan. The amino and hydroxyl groups in chitosan can be coordinated with metal ions to from stable complex. However, chitosan bead, as an adsorbent, has some disadvantages such as dissolution in highly acidic solution, low surface area, high cost, poor thermal and mechanical properties ${ }^{22-24}$. Physical or chemical modification of chitosan using different materials has been studied to improve its properties and adsorption capacity. Chitosan composites such as chitosan/zeolite ${ }^{25}$, chitosan/ lignin ${ }^{26}$, chitosan/ $\mathrm{MgO}^{27}$, nano-hydroxyapatite/chitosan ${ }^{28}$, and chitosan/polyacrylonitrile ${ }^{29}$ have been developed to exhibit better adsorption together with enhancement in other physical and chemical properties.

Clay is a cheap natural raw material that has been widely used for many years as inorganic filler for plastics and rubbers to reduce the polymer consumption and cost. Montmorillonite (MMT), the main component of bentonite, is a layered aluminosilicate mineral that belongs to the montmorillonite/smectite group of clay minerals. Chitosan/ montmorillonite composite prepared by different approaches has successfully employed to adsorb dye ${ }^{30}$, Cobalt (II) ${ }^{31}$, Copper (II) ${ }^{32}$, and tannic acid ${ }^{33}$. However, there have been few reports for using chitosan/montmorillonite composite as an adsorbent to remove silver ion from aqueous solution. 
In this study, chitosan (CTS) and chitosan-montmorillonite (CTS-MMT) composite beads were used to remove silver ions from aqueous solutions by batch adsorption process. Characterization of the composite beads, effect of initial $\mathrm{pH}$, initial metal concentration, contact time and adsorbent dose on the adsorption efficiency of $\mathrm{Ag}^{+}$were studied systemically. The silver ions desorption of adsorbents was also investigated. In addition, the experimental data was examined by evaluating the adsorption isotherms and adsorption kinetic parameters.

\section{Experiment}

\subsection{Materials}

Chitosan (90\% deacetylation degree) was purchased from Seafresh Chitosan (Lab) Co., Ltd. (Thailand). The montmorillonite powder was supplied by Thai Nippon Chemical Industry Co., Ltd. Silver nitrate $\left(\mathrm{AgNO}_{3}\right)$ was used as the source $\mathrm{Ag}^{+}$. Glacial acetic acid was purchased from J.T. Baker (Thailand).

\subsection{Preparation of chitosan-montmorillonite composite beads}

Chitosan-montmorillonite composite beads were prepared by adding montmorillonite powder ( 1 to $5 \mathrm{wt} \%$ of chitosan solution) to $1 \mathrm{~g}$ of chitosan in $50 \mathrm{~mL}$ of $2 \%(\mathrm{v} / \mathrm{v})$ acetic acid solution. The solution was stirred with sonication for $6 \mathrm{~h}$. The chitosan-montmorillonite solution was dropped through a syringe into a precipitation bath containing $1 \mathrm{~L}$ of an alkaline coagulating mixture gave rise to the composite beads. The beads were washed with deionized water and preserved in an aqueous environment for future use.

\subsection{Adsorption studies}

Batch adsorption experiments were carried out using a water bath shaker. For each adsorption experiment, $1 \mathrm{~g}$ adsorbent was dispersed in $100 \mathrm{~mL}$ of $10 \mathrm{mg} / \mathrm{L} \mathrm{AgNO}_{3}$ solution without adjusting the $\mathrm{pH}$ value. The dispersion was stirred at a speed of $100 \mathrm{rpm}$ at $30^{\circ} \mathrm{C}$. The $\mathrm{Ag}^{+}$concentrations were determined by Atomic Absorption Spectroscopy (AAS, Analyst 300). Each experiment was repeated five time under the same controlled conditions. The effect of $\mathrm{pH}$ on adsorption capacities was determined in the $\mathrm{pH}$ range from 4 to 10 . The $\mathrm{pH}$ was adjusted with $0.1 \mathrm{M} \mathrm{NaOH}$ or $0.1 \mathrm{M} \mathrm{HCl}$. Different amounts of the adsorbent in the range of 1 to $5 \mathrm{~g}$ were used to examine the effect of an adsorbent dosage on adsorption of $\mathrm{Ag}^{+}$.

\subsection{Adsorption isotherms}

Adsorption isotherms were obtained by using $1 \mathrm{~g}$ of adsorbent beads and $100 \mathrm{~mL}$ of $\mathrm{AgNO}_{3}$ solution with different concentrations (1-10 mg/L). These solutions were buffered at an optimum $\mathrm{pH}$ for adsorption, i.e., $\mathrm{pH}$ 6. The dispersions were stirred in a water bath shaker until they reached adsorption equilibrium, i.e., $150 \mathrm{~min}$. The quantity of adsorbed $\mathrm{Ag}^{+}$was derived from the concentration change.

\subsection{Adsorption kinetics}

Adsorption kinetics experiments were carried out by varying concentration of $\mathrm{AgNO}_{3}$ solution from $2-10 \mathrm{~mL}$ and stirring in water bath shaker at $30{ }^{\circ} \mathrm{C}$ for time varying from $0-150 \mathrm{~min}$. At the end of each adsorption period and the $\mathrm{Ag}^{+}$concentrations were analyzed similarly.

\subsection{Desorption studies}

Desorption experiment were performed in order to estimate to the metal releasing capacity of chitosan-montmorillonite with $\mathrm{Ag}^{+}$. The adsorbent was used $1 \mathrm{~g}$ for adsorbing $\mathrm{Ag}^{+}$ ions in $100 \mathrm{~mL}$ of $\mathrm{AgNO}_{3}$ solution $(10 \mathrm{mg} / \mathrm{L})$ at $\mathrm{pH} 4,7$ and 10 . The adsorbent was washed with deionized water to remove any unabsorbed $\mathrm{Ag}^{+}$. For desorption experiment was carried out using $100 \mathrm{~mL}$ of $10 \mathrm{mM}$ acetic acid solution with a constant stirring $(100 \mathrm{rpm})$ at $30{ }^{\circ} \mathrm{C}$ for $150 \mathrm{~min}$. The desorption ratio was calculated from the number of metal ions adsorbed on the adsorbent and the final metal concentration in desorption medium, according to the following equation:

Desorption ratio $=\frac{\text { amount of metal ions desorbed }}{\text { amount of metal ions adsorbed }} \times 100$

\subsection{Characterization}

The X-ray diffraction (XRD) patterns were obtained using a Bruker D8 advance with a monochromatic $\mathrm{Cu} \mathrm{K} \alpha$ source $(\lambda=0.15418 \mathrm{~nm})$ operating at $40 \mathrm{kV}$ and $40 \mathrm{~mA}$. The diffraction patterns were recorded from $3^{\circ}$ and $40^{\circ}$ with a scan rate of $0.4 \mathrm{sec} /$ step. The morphology of CTS and CTS-MMT composite beads were characterized by scanning electron microscopy (SEM, JEOL JSM-6335F) and energy dispersive X-ray spectroscopy (EDX, Oxford). The Zeta potential was measured using a Zetasizer (ZS90, Malvern). The $\mathrm{pH}$ value of the CTS and CTS-MMT composite beads were adjusted between $4-10$ by adding $\mathrm{HCl}$ and $\mathrm{NaOH}$.

\section{Results and discussion}

\subsection{Structure analysis}

The XRD patterns of CTS, MMT and CTS-MMT are shown in Figure 1. The (001) diffraction peak of MMT occurred at $2 \theta$ of $6.05^{\circ}$, corresponding to a d 001 spacing of $14.58 \AA$. However, the d001 spacing of CTS-1\%MMT was slightly increased to $15.29 \AA\left(2 \theta=5.78^{\circ}\right)$, and CTS-3\%MMT was shifted to $15.39 \AA\left(2 \theta=5.74^{\circ}\right)$. It indicated that the MMT interlayer was expanded, which can be reasonably ascribed to the intercalation of CTS into the MMT interlayer region, leading to the formation of CTS-MMT composite bead. 


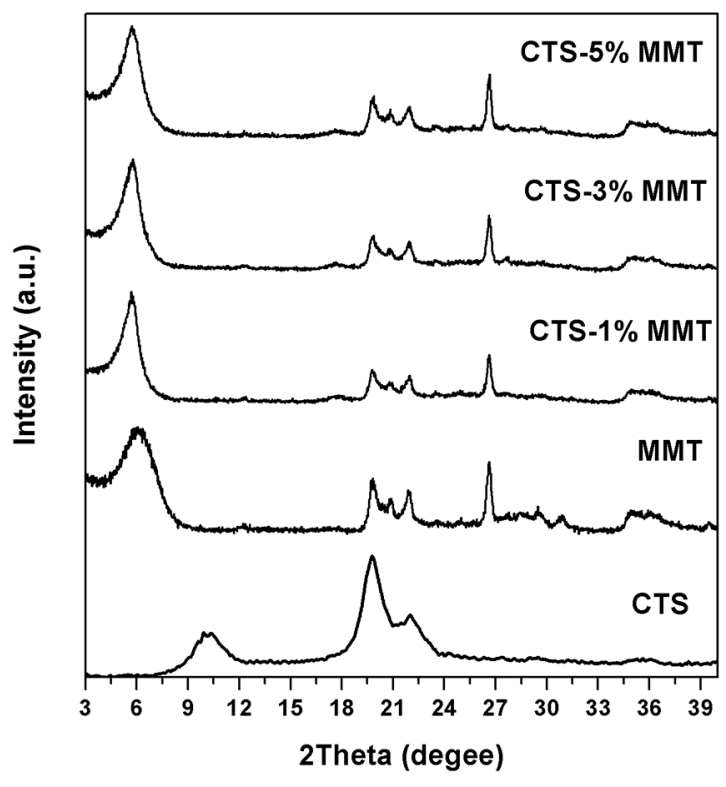

Figure 1: XRD patterns of CTS, MMT, and CTS-MMT composite beads.

\subsection{Zeta potential analysis}

Solution $\mathrm{pH}$ was an important parameter that affected the adsorption of $\mathrm{Ag}^{+}$. The Zeta potential of CTS and CTS-MMT composite beads as a function of the solution $\mathrm{pH}$ values were shown in Figure 2. Solution $\mathrm{pH}$ determined the level of electrostatic or molecular interaction between the adsorption surface and adsorbate owing to charge distribution on the materials. The zero point charge or isoelectric point $\left(\mathrm{pH}_{\mathrm{zpc}}\right)$ of the CTS was about 7.1 and then shifted to 7.5 after being modified by MMT. The difference in $\mathrm{pH}_{\text {zpc }}$ between them confirmed that CTS was successfully coated on MMT composite bead. The $\mathrm{pH}_{\text {zpc }}$ of $\mathrm{CTS}$ was obtained at $\mathrm{pH}=7.1$ for amino group in chitosan. This result was similar to some finding in previous studies ${ }^{24}$. At below $\mathrm{pH} 7.5$, more amino groups in the CTS-MMT composite beads were protonated (i.e., from $-\mathrm{NH}_{2}$ to $-\mathrm{NH}_{3}^{+}$). From $\mathrm{pH}$ 7.5 to 10 , the negative zeta potential of CTS-MMT composite bead, which amino group in CTS-MMT composite bead was not deprotonated under this $\mathrm{pH}$ condition (i.e., from $-\mathrm{NH}_{2}$ to $-\mathrm{NH}$ ). Moreover, Figure 2 revealed that the adsorption capacity of CTS-MMT composite bead was highly depended on the positive charge at $\mathrm{pH}<7.5$.

\subsection{Morphology}

Figure 3 showed the SEM image of the CTS and CTSMMT composite bead. It can be seen that the morphology of CTS and CTS-MMT composite beads exhibited notable smooth surface and spherical structure (Figure 3 (a) and (d)). The EDX mapping also indicated that $\mathrm{Ag}$ was found to be uniformly distributed along surface of the beads (Figure 1 (b) and (e)). In comparison, the bright contrast speckles of Ag

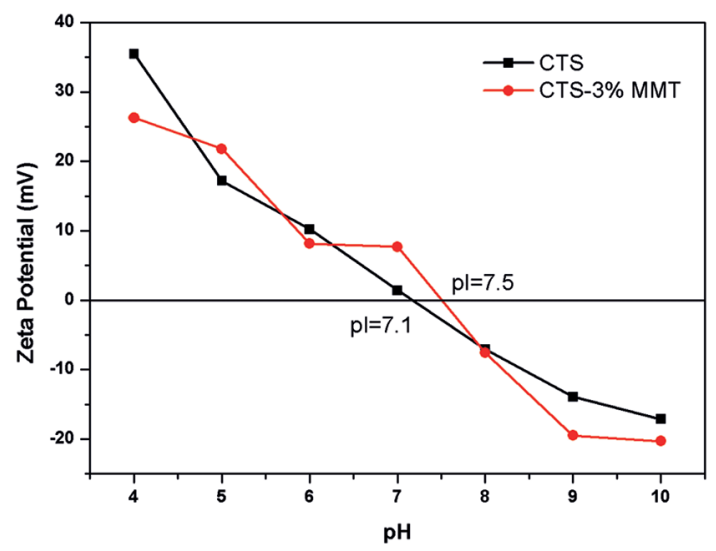

Figure 2: Zeta potentials of the CTS and CTS-3\%MMT composite beads.
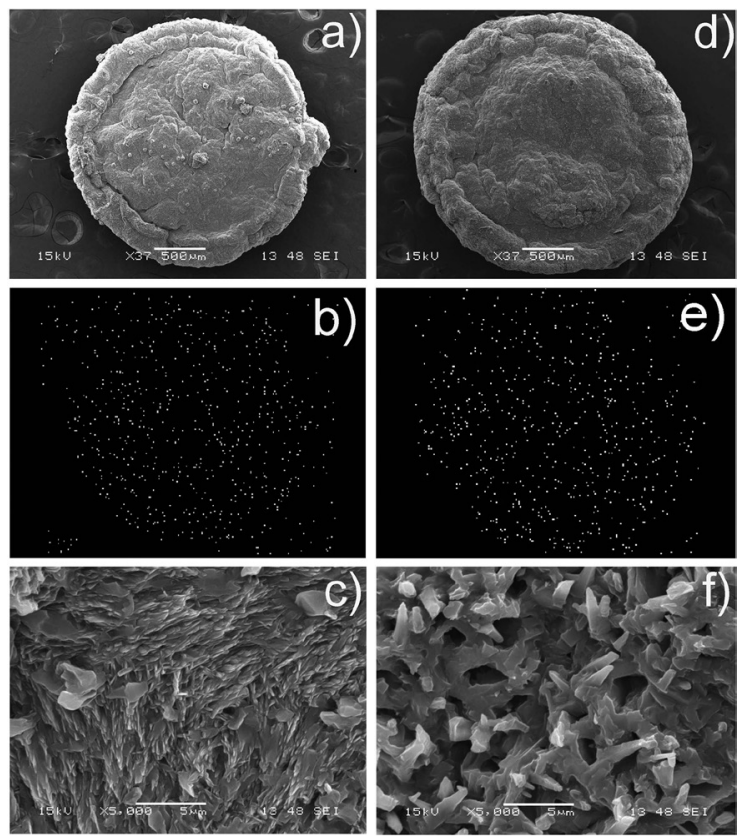

Figure 3: SEM image and EDX mapping of CTS (a-c) and CTS$3 \%$ MMT composite beads after $\mathrm{Ag}^{+}$adsorption (d-f).

were more densely distributed at CTS-MMT than CTS beads. From Figure 3 (c) and (f), the SEM image of CTS-MMT composite bead showed that high porous and agglomerated particles due to the irregular stacking of MMT particles. This result suggested that the adsorption of composite bead was governed by electrostatic forces and natural entrapment in to the porous CTS and MMT materials.

\subsection{Effect of contact time}

Contact time was another important parameter for adsorption efficiency of metal ions. The effect of contact time on the absorption of $\mathrm{Ag}^{+}$ion on CTS and CTS-MMT composite bead was shown in Figure 4. The result showed 


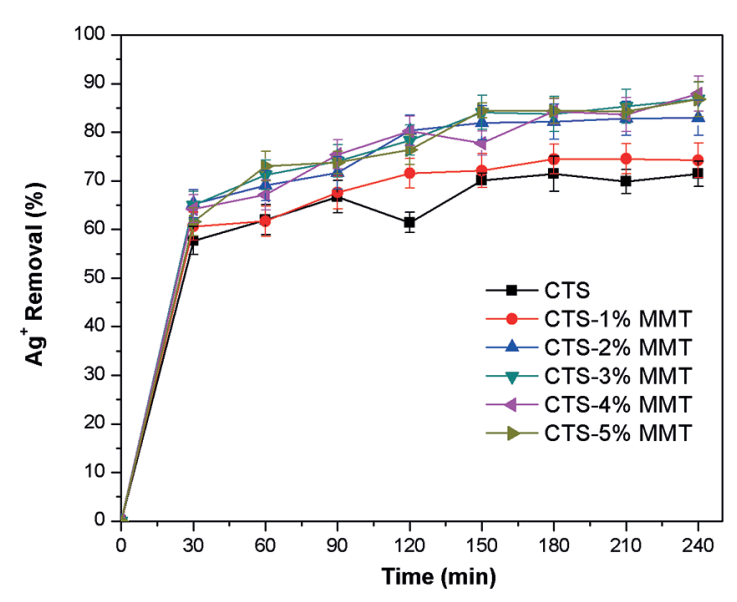

Figure 4: Effects of contact time and MMT concentration in bead on $\mathrm{Ag}^{+}$removal (adsorbent dosage: $1 \mathrm{~g}$; $\mathrm{Ag}^{+}$concentration: $10 \mathrm{mg} / \mathrm{L}$; volume: $100 \mathrm{~mL}$; $\mathrm{pH}: 7)$.

that the $\mathrm{Ag}^{+}$was rapidly adsorbed in the first $30 \mathrm{~min}$ with the increase of contact time from 0-30 min and the $\mathrm{Ag}^{+}$removal increased to about $84 \%$ within $150 \mathrm{~min}$. After $150 \mathrm{~min}$, the adsorption rate becomes constant and the adsorption reach equilibrium. At this (equilibrium) time, the adsorption rate of CTS-MMT composite beads was higher than pure CTS bead. In addition, the $\mathrm{Ag}^{+}$removal of CTS-MMT composite bead increased with increasing of MMT particles concentration in the composite beads. The maximum of $\mathrm{Ag}^{+}$removal was $84.11 \%$ for CTS-3\%MMT and $84.44 \%$ for CTS-5\%MMT composite bead at contact time $150 \mathrm{~min}$.

\subsection{Effect of $p H$}

The $\mathrm{pH}$ of the aqueous solution, the most important parameter on adsorption studies, strongly affected the adsorption property of beads for heavy metal ions. From Figure 5 , the $\mathrm{pH}$ value of the solution increased from 5 to 6, the $\mathrm{Ag}^{+}$removal of adsorbent increased sharply from $57.57 \%$ to $77.28 \%$ for CTS-3\%MMT composite bead, and slightly increased to $78.31 \%$ with the increasing of the $\mathrm{pH}$ from 6 to 7. However, the mechanisms of adsorption of $\mathrm{Ag}^{+}$ may be considered the electrostatic interaction between the protonated group of CTS and $\mathrm{Ag}^{+}$and chemical reaction between adsorbate and the adsorbent. The primary amine group of the CTS structure was about $\mathrm{pH} 6$ to 7. It was noted that an acidic $\mathrm{pH}$ value was necessary to provide $-\mathrm{NH}_{3}{ }^{+}$ groups in the CTS structure facilitating an increase of $\mathrm{Ag}^{+}$ adsorption, which corresponding to the point of zero charge result (Figure 2). The relative lower adsorption below solution $\mathrm{pH}$ of 6 may be due to the competitive adsorption between proton and $\mathrm{Ag}^{+}$ions on CTS. Above $\mathrm{pH} \mathrm{7,} \mathrm{as} \mathrm{insoluble}$ silver hydroxide started to precipitate from solution, both adsorption and precipitate were effective mechanism in the removal of $\mathrm{Ag}^{+}$ions from aqueous solution. The precipitation of silver hydroxide increased dramatically when the solution

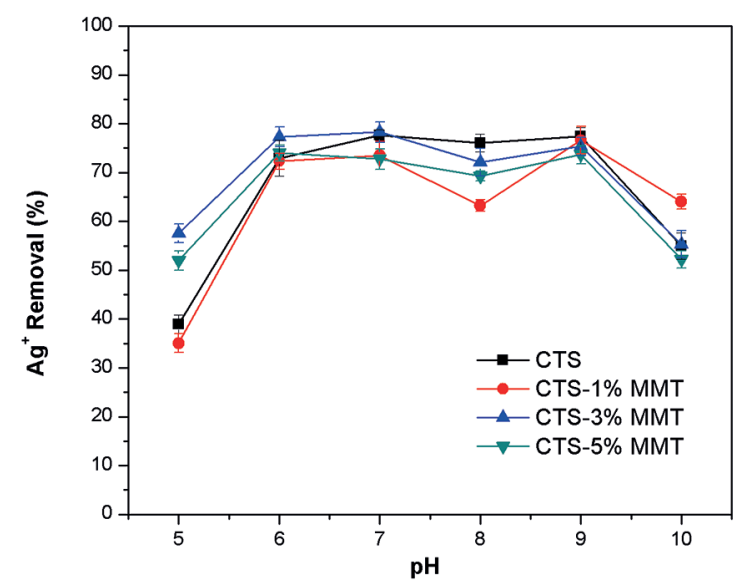

Figure 5: Effect of $\mathrm{pH}$ on the $\mathrm{Ag}^{+}$adsorption rate after $150 \mathrm{~min}$ (the weight of MMT: $0,1,3$ and $5 \%$ of chitosan solution; $\mathrm{Ag}^{+}$ concentration: $10 \mathrm{mg} / \mathrm{L}$; volume: $100 \mathrm{~mL}$ ).

$\mathrm{pH}$ of 10 . The higher precipitation can be attributed to more hydroxyl group in the solution. Hence adsorption of $\mathrm{Ag}^{+}$onto CTS-MMT was at optimum $\mathrm{pH}$ range of 6-7.

\subsection{Effect of adsorption dosage}

The adsorbent dosage was an important parameter for the adjusted during wastewater treatment (Figure 6). It was clearly seen that the removal efficiency of $\mathrm{Ag}^{+}$increased from $56 \%$ to $95.7 \%$ which increased in the dosage of from $1 \mathrm{~g}$ to $5 \mathrm{~g}$ at $30 \mathrm{~min}$. Therefore, the removal of $\mathrm{Ag}^{+}$increased with increasing of the adsorbent dosage was attributed to the availability of a larger surface area and more adsorption sites. The adsorption time required to reach equilibrium was decreased with increase dose of adsorbent. Thus, the increase of adsorption rate may be depended on the ratio of adsorbent weight to solution volume, which is corresponded to the increased dose of adsorbent.

\subsection{Adsorption isotherms}

The adsorption process can be generally expressed by two isotherm equations, the Langmuir ${ }^{34}$ and Freundlich equation $^{35}$, which is represented by the following equation:

Langmuir isotherm: $\frac{\mathrm{C}_{\mathrm{e}}}{\mathrm{q}_{\mathrm{e}}}=\frac{1}{\mathrm{bX}_{\mathrm{m}}}+\frac{\mathrm{C}_{\mathrm{e}}}{\mathrm{X}_{\mathrm{m}}}(2)$

Freundlich isotherm: $\log \mathrm{q}_{\mathrm{e}}=\log \mathrm{K}+\frac{1}{\mathrm{n}} \log \mathrm{C}_{\mathrm{e}}$

Where $q_{e}$ is the amount of $\mathrm{Ag}^{+}$adsorbed per unit mass of adsorbent $(\mathrm{mg} / \mathrm{g})$ and $C_{e}$ is the equilibrium concentration of $\mathrm{Ag}^{+}$in solution $(\mathrm{mg} / \mathrm{L})$. The constant $X_{m}$ is the monolayer adsorption capacity $(\mathrm{mg} / \mathrm{g})$, and $b$ is the Langmuir constant related to the adsorption energy. $K$ $(\mathrm{mg} / \mathrm{g})$ is the Freundlich constant related to the adsorption capacity of the adsorption, and $n$ measures the surface 


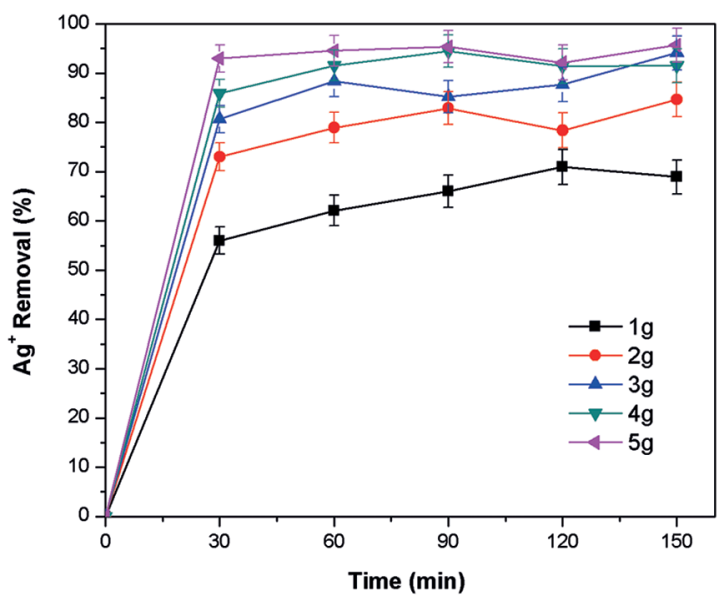

Figure 6: Effects of adsorbent dosage on $\mathrm{Ag}^{+}$ramoval (the weight of MMT: $3 \%$ of chitosan solution; $\mathrm{pH}$ : $6 ; \mathrm{Ag}^{+}$concentration: 10 $\mathrm{mg} / \mathrm{L}$; volume: $100 \mathrm{~mL}$; contact time: $150 \mathrm{~min}$ ).

heterogeneity. The linear regression analysis was performed using OriginPro 8 software to determine $K$ and $X_{m}$ and standard errors regarding with the model parameter. The isotherm constants of Langmuir and Freundlich were calculated from the plots of $C_{e} / q_{e}$ vs. $C_{e}$ and $\log q_{e}$ vs. $\log C_{e}$ as depicted from Figure 7 , respectively, and the results were listed in Table 1 . Therefore, the sorption capacity $X_{m}$, which was a measure of the maximum sorption capacity corresponding to complete monolayer coverage, showed that the CTS-MMT composite bead had a higher adsorption capacity $\left(X_{m}=43.48 \mathrm{mg} / \mathrm{g}\right)$ than that of CTS bead $\left(X_{m}=38.46 \mathrm{mg} / \mathrm{g}\right.$ ). The $b$ value was 1.00 for CTS and 2.87 for CTS-MMT, indicating that adsorption strength was not very strong. Moreover, the Freundlich isotherm parameter $1 / n$ is a measure of the deviation from linearity of the adsorption. The low value of CTS (0.84) and CTS-MMT composite bead (0.74) less than 1 showed the favorable sorption and confirmed the heterogeneity of the adsorbent. Also, the results indicated that the bond between $\mathrm{Ag}^{+}$and composite bead were strong. The adsorption capacity $K$ of the adsorbent was calculated from the isothermal linear regression equation. The $K$ value of CTS-MMT composite bead $(1.30 \mathrm{mg} / \mathrm{g})$ was higher than that of CTS bead $(1.01 \mathrm{mg} / \mathrm{g})$, confirming that CTS-MMT composite bead had higher adsorption. For fitting to Langmuir and Freundlich model, the linear regression coefficients $\left(\mathrm{R}^{2}\right)$ were 0.95 and 0.92 for CTSMMT composite bead, respectively (Table 1). It was clear that the correlation coefficients for the Langmuir isotherm were somewhat higher than for the Freundlich isotherm. This indicated that the uptake occurred on a homogenous surface by monolayer adsorption, and can be described in terms of chemisorption as the formation of ionic bonds between adsorbent and adsorbate.
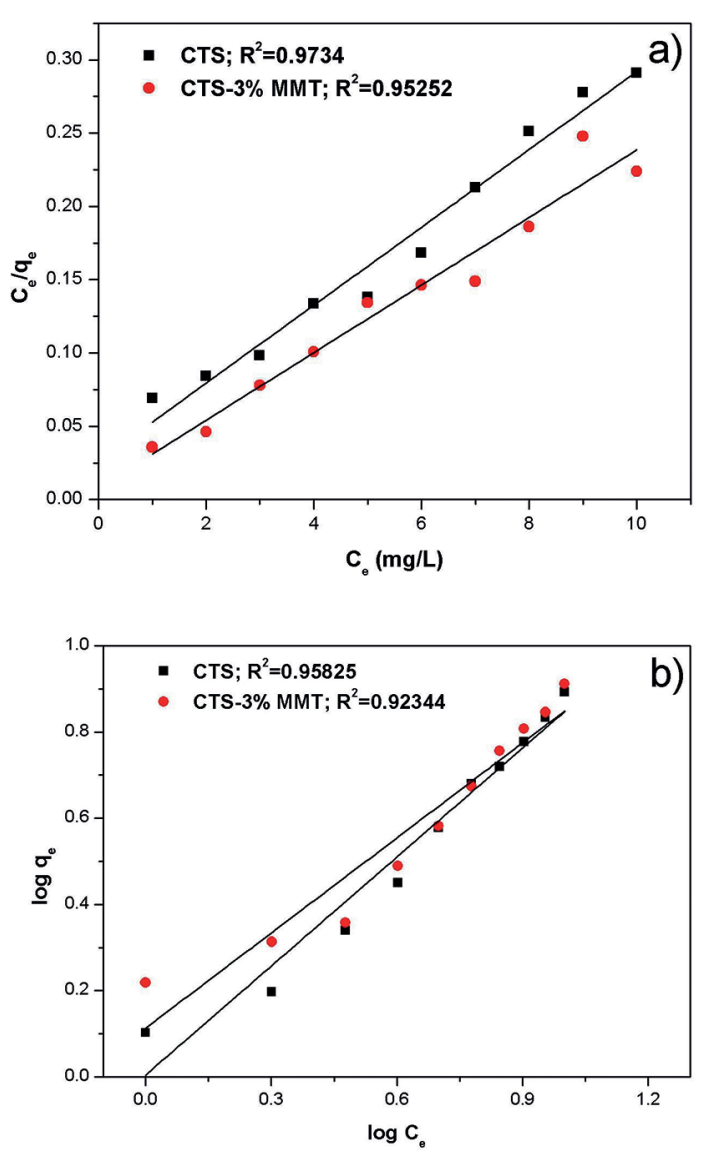

Figure 7: Isotherm plot for the adsorption of CTS and CTS3\%MMT composite beads; a) The Langmuir adsorption model and b) Freundlich adsorption model where the line were the best fit linear regression lines.

\subsection{Adsorption kinetics}

The kinetic parameter, which was helpful for the prediction of adsorption rate, gives important information for designing and modeling the processes. The kinetic of the adsorption data was analyzed using different kinetic models such as pseudo-first-order and pseudo-second-order models, which is represented by the following equation:

pseudo-first-order model:

$$
\log \left(q_{e}-q_{t}\right)=\log q_{e}-\frac{k_{1}}{2.303} t
$$

pseudo-second-order:

$$
\frac{\mathrm{t}}{\mathrm{q}_{\mathrm{t}}}=\frac{1}{\mathrm{k}_{2} \mathrm{q}_{\mathrm{e}}^{2}}+\frac{\mathrm{t}}{\mathrm{q}_{\mathrm{e}}}
$$

where $q_{e}$ is the amount of $\mathrm{Ag}^{+}$ions adsorption equilibrium $(\mathrm{mg} / \mathrm{g}), q_{t}(\mathrm{mg} / \mathrm{g})$ is the amount of $\mathrm{Ag}^{+}$ions adsorbed at any time $t(\mathrm{~min})$, and $K_{1}\left(\mathrm{~min}^{-1}\right)$ and $K_{2}(\mathrm{~g} / \mathrm{mg} \mathrm{min})$ are the rate constants of the pseudo first order and pseudo second order 
Table 1: Parameter of the Langmuir and Freundlich isotherm models for CTS and CTS-3\%MMT composite beads.

\begin{tabular}{lcccc}
\hline \multicolumn{5}{c}{ Langmuir isotherm model } \\
\hline Type of adsorbent & Parameter & Value & Standard error & $\mathrm{R}^{2}$ \\
CTS & $\mathrm{X}_{\mathrm{m}}$ & 38.46 & 0.00146 & 0.97344 \\
& $\mathrm{~b}$ & 1.00 & 0.00906 & 0.95253 \\
CTS-MMT & $\mathrm{X}_{\mathrm{m}}$ & 43.48 & 0.00171 & 0.95825 \\
& $\mathrm{~b}$ & 2.87 & 0.01061 & 0.04228 \\
\hline CTS & $\mathrm{k}$ & Freundlich isotherm model & 0.05855 & 0.92344 \\
& $1 / \mathrm{n}$ & 1.01 & 0.05078 & 0.07031 \\
\hline
\end{tabular}

adsorption models. The values of $K_{1}$ and $q_{e}$ were calculated from slope and intercept of the plot of $\log \left(q_{e}-q_{t}\right)$ vs. $t$ (Figure 8 ), while the values of $K_{2}$ and $q_{e}$ were evaluated from the intercept and slope of a plot $t / q_{t}$ vs. $t$. Table 2 summarized the value of the corresponding model parameters.

From Table 2, it can be seen that the linear correlation coefficients $\left(R^{2}\right)$ for the pseudo-first order kinetic model were very low. The large difference between the experiment $q_{e}$ value $\left(q_{\text {e(exp) }}\right)$ and the calculated $q_{e}$ value $\left(q_{e(c a l)}\right)$, which indicated the pseudo first order kinetic model was poor fit for the adsorption processes of CTS-MMT composite bead for $\mathrm{Ag}^{+}$. It can also be found from Table 2 that $R^{2}$ for pseudo second order kinetic model were all over 0.9 . Moreover, the $q_{\text {e(cal) }}$ value for the pseudo second order kinetic model were consistent with the $q_{\text {e(exp) }}$ value, Therefore, the adsorption process of CTS-MMT composite beads for $\mathrm{Ag}^{+}$can be well described by the pseudo second order kinetic model. This result indicated that the sorption process was complex and involved more than one mechanism.

Table 3 showed that the maximum adsorption capacities reported of different adsorbents for $\mathrm{Ag}^{+}$removal from aqueous solutions $s^{3,17,21,24,36}$. It was found that the CTS-MMT composite bead has a higher adsorption capacity than some other adsorbents. This result could be demonstrated that the CTS-MMT composite beads can be used as effective adsorbents for $\mathrm{Ag}^{+}$removal from aqueous solution.

\subsection{Desorption studies}

Recovery of adsorbent was very important feature for the industrial applications. Table 4 showed the relationship between the $\mathrm{pH}$ and the desorption efficiency of the CTS and CTS-MMT composite bead. It can be seen that the maximum desorption of saturated adsorbent was $30.39 \%$ and $17.39 \%(\mathrm{pH}=4)$ for CTS and CTS-MMT composite bead, respectively. This result indicated that adsorption $\mathrm{Ag}^{+}$on adsorbents can be desorption by acetic acid solution. The desorption efficiency of CTS and CTS-MMT composite
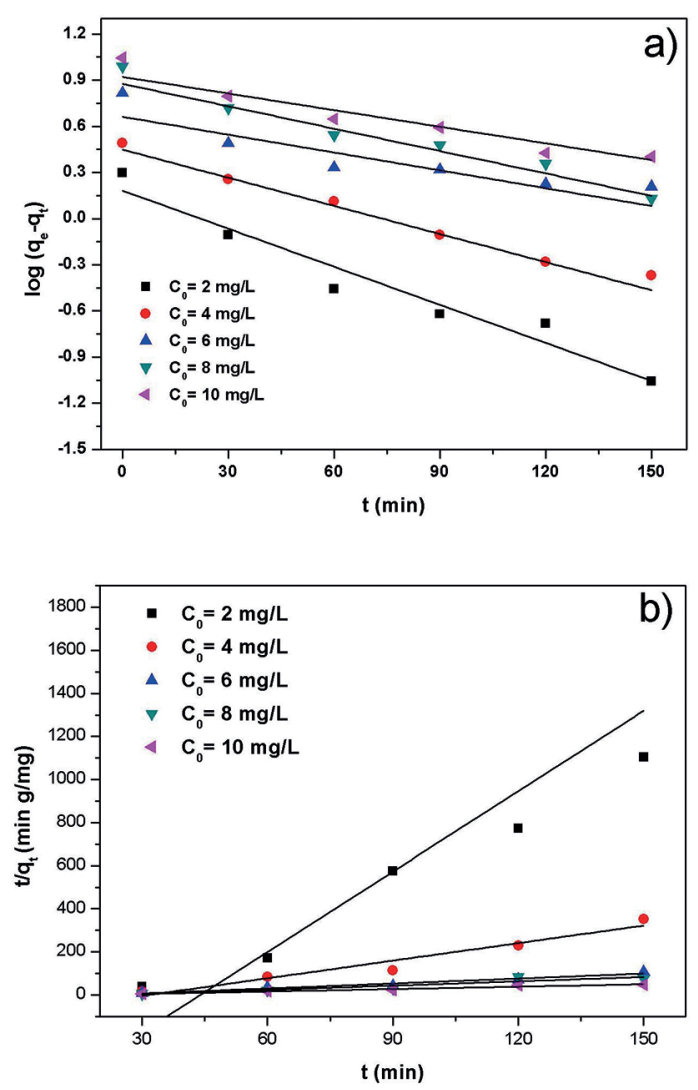

Figure 8: Fitting with different kinetic model at different concentration (a) Pseudo-first-order model, and (b) Pseudo-second-order model for CTS-3\%MMT composite bead.

bead was increased with decease of $\mathrm{pH}$. The decrease in desorption efficiency of the metal ions may be explained by the fact that at the MMT surface was higher negative charged, hence large attraction between the positive $\mathrm{Ag}^{+}$ occurred. This implied that the CTS and CTS-MMT composite bead were potential of regeneration and reuse. 
Table 2: Constants and correlation coefficient of two kinetic models for $\mathrm{Ag}^{+}$adsorption onto CTS-3\%MMT composite bead at different concentration (adsorbent dose: $1 \mathrm{~g}$; Volume: $100 \mathrm{~mL}$; pH: 6)

\begin{tabular}{lccccccc}
\hline $\mathrm{C}_{0}(\mathrm{mg} / \mathrm{L})$ & $\mathrm{q}_{\mathrm{e}(\exp )}(\mathrm{mg} / \mathrm{g})$ & $\mathrm{q}_{\mathrm{e}(\mathrm{cal})}(\mathrm{mg} / \mathrm{g})$ & $\mathrm{K}_{1}(1 / \mathrm{min})$ & $\mathrm{R}^{2}$ & $\mathrm{q}_{\mathrm{e}(\mathrm{cal})}(\mathrm{mg} / \mathrm{g})$ & $\mathrm{K}^{2}(\mathrm{~g} / \mathrm{mg} \mathrm{min})$ & $\mathrm{R}^{2}$ \\
\hline 2 & 0.44 & 1.51 & $18.4 \times 10^{-3}$ & 0.93 & 0.11 & 0.15 & 0.97 \\
4 & 0.91 & 2.75 & $13.8 \times 10^{-3}$ & 0.84 & 0.36 & 0.09 & 0.93 \\
6 & 1.27 & 4.59 & $6.9 \times 10^{-3}$ & 0.71 & 1.30 & 0.04 & 0.95 \\
8 & 1.56 & 7.51 & $9.2 \times 10^{-3}$ & 0.78 & 1.51 & 0.03 & 0.91 \\
10 & 1.83 & 8.33 & $6.9 \times 10^{-3}$ & 0.71 & 2.70 & 0.02 & 0.93 \\
\hline
\end{tabular}

Table 3: Comparison among adsorption of different adsorbents for $\mathrm{Ag}^{+}$.

\begin{tabular}{lcc}
\hline Adsorbent & Adsorption capacity $(\mathrm{mg} / \mathrm{g})$ & Reference \\
\hline RH & 1.62 & {$[36]$} \\
EP & 8.46 & {$[3]$} \\
CTS/MMT & 43.48 & This work \\
CTS/BC & 52.91 & {$[24]$} \\
Mn-MV & 69.2 & {$[17]$} \\
IGCC & 89.2 & {$[21]$} \\
\hline
\end{tabular}

Table 4: Desorption of $\mathrm{Ag}^{+}$from CTS and CTS-3\%MMT composite bead.

\begin{tabular}{lcc}
\hline Type of adsorbent & $\mathrm{pH}$ & Desorption ratio (\%) \\
\hline \multirow{3}{*}{ CTS } & 4 & 30.39 \\
& 7 & 9.26 \\
& 10 & 6.00 \\
CTS-MMT & 4 & 17.39 \\
& 7 & 7.00 \\
\hline
\end{tabular}

\section{Conclusions}

This study proved that $\mathrm{Ag}^{+}$could be adsorbed and thus higher significant amount was removed by CTS-MMT composite bead from aqueous solution. The maximum adsorption capacity of CTS-MMT composite bead was higher than those CTS bead. $\mathrm{The} \mathrm{Ag}^{+}$removal was increased with the increase of contact time and amount of adsorbent. The optimum $\mathrm{pH}$ value for $\mathrm{Ag}^{+}$ removal was found to be 6-7. The equilibrium data could be described by the Langmuir and Freundlich isotherm equation. However, the Langmuir model better represented the sorption process than the Freundlich model. The maximum adsorption capacity of CTS-MMT composite bead was $43.48 \mathrm{mg} / \mathrm{g}$ at initial $\mathrm{pH} 6$ for $10 \mathrm{mg} / \mathrm{L}\left(\mathrm{Ag}^{+}\right)$solution. Kinetic modeling results showed that the pseudo second order equation was appropriated for the description of this type of adsorption and removal. The desorption studies revealed that the CTS and CTS-MMT composite bead provide the potential for reused after $\mathrm{Ag}^{+}$adsorption.

\section{Acknowledgements}

This research is financially supported by the Srinakharinwirot University. The authors would like to thank the Department of Chemistry, Faculty of Science, Srinakharinwirot University for the Atomic Adsorption Spectroscopy.

\section{References}

1. Rao GP, Lu C, Su F. Sorption of divalent metal ions from aqueous solution by carbon nanotubes: A review. Separation and Purification Technology. 2007;58(1):224-231. http://dx.doi. org/10.1016/j.seppur.2006.12.006.

2. Song X, Gunawan P, Jiang R, Leong SSJ, Wang K, Xu R. Surface activated carbon nanospheres for fast adsorption of silver ions from aqueous solutions. Journal of Hazardous Materials. 2011;194:162168. http://dx.doi.org/10.1016/j.jhazmat.2011.07.0760.

3. Ghassabzadeh H, Mohadespour A, Torab-Mostaedi M, Zaheri P, Maragheh MG, Taheri $\mathrm{H}$. Adsorption of $\mathrm{Ag}, \mathrm{Cu}$ and $\mathrm{Hg}$ from aqueous solutions using expanded perlite. Journal of Hazardous Materials. 2010;177(1-3):950-955. http://dx.doi.org/10.1016/j. jhazmat.2010.01.010.

4. Coruh S, Senel G, Ergun ON. A comparison of the properties of natural clinoptilolites and their ion-exchange capacities for silver removal. Journal of Hazardous Materials. 2010;180(13):486-492. http://dx.doi.org/10.1016/j.jhazmat.2010.04.056.

5. Huo H, Su H, Tan T. Adsorption of $\mathrm{Ag}^{+}$by a surface molecularimprinted biosorbent. Chemical Engineering Journal. 2009;150(1):139-144. http://dx.doi.org/10.1016/j.cej.2008.12.014.

6. San A, Tüzen M. Adsorption of silver from aqueous solution onto raw vermiculite and manganese oxide-modified vermiculite. Microporous and Mesoporous Materials. 2013;170:155-163. http://dx.doi.org/10.1016/j.micromeso.2012.12.004.

7. Virolainen S, Tyster M, Haapalainen M, Sainio T. Ion exchange recovery of silver from concentrated base metal-chloride solutions. Hydrometallurgy. 2015;152:100-106. http://dx.doi. org/10.1016/j.hydromet.2014.12.011.

8. Behnamfard A, Salarirad MM, Veglio F. Process development for recovery of copper and precious metals from waste printed circuit boards with emphasize on palladium and gold leaching and precipitation. Waste Management. 2013;33(11):2354-2363. http://dx.doi.org/10.1016/j.wasman.2013.07.017.

9. Behbahani M, Najafi F, Amini MM, Sadeghi O, Bagheri A, Hassanlou PG. Solid phase extraction using nanoporous MCM41 modified with 3,4-dihydroxybenzaldehyde for simultaneous preconcentration and removal of gold(III), palladium(II), copper(II) and silver(I). Journal of Industrial and Engineering Chemistry. 2014;20(4):2248-2255. http://dx.doi.org/10.1016/j. jiec.2013.09.057. 
10. Sun Q, Li Y, Tang T, Yuan Z, Yu CP. Removal of silver nanoparticles by coagulation processes. Journal of Hazardous Materials. 2013;261:414-420. http://dx.doi.org/10.1016/j. jhazmat.2013.07.066.

11. Das D, Das N, Mathew L. Kinetics, equilibrium and thermodynamic studies on biosorption of $\mathrm{Ag}(\mathrm{I})$ from aqueous solution by macrofungus Pleurotus platypus. Journal of Hazardous Materials. 2010;184(13):765-774. http://dx.doi.org/10.1016/j.jhazmat.2010.08.105.

12. Wu JJ, Lee HW, You JH, Kau YC, Liu SJ. Adsorption of silver ions on polypyrrole embedded electrospun nanofibrous polyethersulfone membranes. Journal of Colloid and Interface Science. 2014;420:145151. http://dx.doi.org/10.1016/j.jcis.2014.01.011

13. Weng $\mathrm{CH}$, Huang CP. Adsorption characteristics of $\mathrm{Zn}$ (II) from dilute aqueous solution by fly ash. Colloids and Surfaces A: Physicochemical and Engineering Aspects. 2004;247(1-3):137143. http://dx.doi.org/10.1016/j.colsurfa.2004.08.050.

14. Santona L, Castaldi P, Melis P. Evaluation of the interaction mechanisms between red muds and heavy metals. Journal of Hazardous Materials. 2006;136(2):324-329. http://dx.doi. $\operatorname{org} / 10.1016 /$ j.jhazmat.2005.12.022.

15. Balkaya N, Cesur H. Adsorption of cadmium from aqueous solution by phosphogypsum. Chemical Engineering Journal. 2008;140(1-3):247-254. http://dx.doi.org/10.1016/j.cej.2007.10.002.

16. Yurtsever M, Şengil IA. Adsorption and desorption behavior of silver ions onto valonia tannin resin. Transaction of Nonferrous Metals Society of China. 2012;22(11):2846-2854. http://dx.doi. org/10.1016/S1003-6326(11)61541-0.

17. Sari A, Tüzen M. Adsorption of silver from aqueous solution onto raw vermiculite and manganese oxide-modified vermiculite. Microporous and Mesoporous Materials. 2013;170:155-163. http://dx.doi.org/10.1016/j.micromeso.2012.12.004.

18. Bassi R, Prasher SO, Simpson BK. Removal of selected metal ions from aqueous solutions using chitosan flakes. Separation Science and Technology. 2000;35(4):547-560. http://dx.doi. org/10.1081/SS-100100175.

19. Chu KH. Removal of copper from aqueous solution by chitosan in prawn shell: adsorption equilibrium and kinetics. Journal of Hazardous Materials. 2002;90(1):77-95. http://dx.doi. org/10.1016/S0304-3894(01)00332-6.

20. Guibal E. Interactions of metal ions with chitosan-based sorbents: a review. Separation and Purification Technology. 2004;38(1):4374. http://dx.doi.org/10.1016/j.seppur.2003.10.004.

21. Zhang M, Helleur R, Zhang Y. Ion-imprinted chitosan gel beads for selective adsorption of $\mathrm{Ag}^{+}$from aqueous solutions. Carbohydrate Polymers. 2015;130:206-212. http://dx.doi. org/10.1016/j.carbpol.2015.05.038.

22. Chatterjee S, Lee MW, Woo SH. Adsorption of congo red by chitosan hydrogel beads impregnated with carbon nanotubes. Bioresource Technology. 2010;101(6):1800-1806. http://dx.doi. org/10.1016/j.biortech.2009.10.051.

23. Pérez-Fonseca AA, Gómez C, Dávila H, González-Núñez R, Robledo-Ortíz JR, Vázquez-Lepe MO, et al. Chitosan supported onto agave fiber-postconsumer HDPE composites for $\mathrm{Cr}(\mathrm{VI})$ adsorption. Industrial \& Engineering Chemistry Research. 2012;51(17):5939-5946. http://dx.doi.org/10.1021/ie201242x.
24. Nitayaphat W, Jintakosol T. Removal of silver(I) from aqueous solutions by chitosan/bamboo charcoal composite beads. Journal of Cleaner Production. 2015;87:850-855. http://dx.doi. org/10.1016/j.jclepro.2014.10.003.

25. Wan Ngah WS, Teong LC, Toh RH, Hanafiah MAKM. Comparative study on adsorption and desorption of $\mathrm{Cu}(\mathrm{II})$ ions by three types of chitosan-zeolite composites. Chemical Engineering Journal. 2013;223:231-238. http://dx.doi. org/10.1016/j.cej.2013.02.090.

26. Nair V, Panigrahy A, Vinu R. Development of novel chitosanlignin composites for adsorption of dyes and metal ions from wastewater. Chemical Engineering Journal. 2014;254:491-502. http://dx.doi.org/10.1016/j.cej.2014.05.045.

27. Haldorai Y, Shim JJ. An efficient removal of methyl orange dye from aqueous solution by adsorption onto chitosan/MgO composite: A novel reusable adsorbent. Applied Surface Science. 2014;292:447-453. http://dx.doi.org/10.1016/j. apsusc.2013.11.158.

28. Salah TA, Mohammad AM, Hassan MA, El-Anadouli BE. Development of nano-hydroxyapatite/chitosan composite for cadmium ions removal in wastewater treatment. Journal of the Taiwan Institute Chemical Engineers. 2014;45(4):1571-1577. http://dx.doi.org/10.1016/j.jtice.2013.10.008.

29. Anitha T, Senthil Kumar P, Kumar KS, Ramkumar B, Ramalingam $\mathrm{S}$. Adsorptive removal of $\mathrm{Pb}$ (II) ions from polluted water by newly synthesized chitosan-polyacrylonirile blend: Equilibrium, kinetic, mechanism and thermodynamic approach. Process Safety and Environmental Protection. 2015;98:187-197. http:/ dx.doi.org/10.1016/j.psep.2015.07.012.

30. Nesic AR, Velicovic SJ, Antonovic DG. Characterization of chitosan/montmorillonite membranes as adsorbents for Bezactiv Orange V-3R dye. Journal of Hazardous Materials. 2012;209210:256-263. http://dx.doi.org/10.1016/j.jhazmat.2012.01.020.

31. Wang H, Tang H, Liu Z, Zhang X, Hao Z, Liu Z. Removal of cobalt(II) ion from aqueous solution by chitosan-montmorillonite. Journal of Environment Sciences. 2014;26(9):1879-1884. http:// dx.doi.org/10.1016/j.jes.2014.06.021

32. Pereira FAR, Sousa KS, Cavalcanti GRS, Fonseca MG, Souza AG, Alves APM. Chitosan-montmorillonite biocomposite as an adsorbent for copper (II) cations from aqueous solutions. International Journal of Biological Macromolecules. 2013;61:471478. http://dx.doi.org/10.1016/j.ijbiomac.2013.08.017.

33. An JH, Dultz S. Adsorption of tannic acid on chitosanmontmorillonite as a function of $\mathrm{pH}$ and surface charge properties. Applied Clay Science. 2007;36(4):256-264. http:// dx.doi.org/10.1016/j.clay.2006.11.001.

34. Langmuir I. The adsorption of gases on plane surface of glass, mica and platinum. Journal of the American Chemical Society. 1918;40(9):1361-1403.http://dx.doi.org/10.1021/ja02242a004.

35. Freundlich H. Über die adsorption in Lösungen. Zeitschrift fur Physikalische Chemie-Leipzig. 1906;57:385-470.

36. Zafar S, Khalid N, Mirza ML. Potential of rice husk for the decontamination of silver ions from aqueous media. Separation Science and Technology. 2012;47(12):1793-1801. http://dx.doi. org/10.1080/01496395.2012.657322. 